\title{
Goodbye Family Gloom! The Coming of Charaxos in the Brothers Song
}

\author{
Dirk Obbink
}

Not long after its publication, Peter Stothard and Mary Beard commissioned seven translators to produce English translations of the Brothers Song. These were printed side-by-side in the Times Literary Supplement, and included some surprising differences, anomalies, and nice touches. But none stood out like the following rendition by the poet Anne Carson: ${ }^{1}$

There you go windbagging about Charaxos again — will he waft into port?

will he not? - yawn. Let the gods simplify this. Or send me! I've got the holy socks and tang to bring Hera over to our side: presto Charaxos, cocktails all round!

Now tip all that other worry into the box marked Looking for a Miracle. Red weather can die away on a dime (as you know) and if some god blows you a kiss, peacocks sweep the room handing out coupons.

As for us-if lazyboy Larichos ever lifts his head and turns into a man who can whistle Dixie goodbye family gloom! We'll run our fingers through his beard and laugh.

Carson's rendering lends the English some of the excitement and color that had me wide-eyed for months when I first read the text in Greek, although it ultimately borders on caricature or parody_mocking, I take it, the whole interpretive tradition of preciousness. A poem of this exuberance and vibrancy could also be obtained by applying the 'wild' reading recently advanced by

1 Carson, Janko, McDonald and Stallings (2014). These were followed by an additional three in the $T L S$ on May 2, 2014, p. 23 by Alistair Elliot, Andrew McNellie, and Rachel Hadas.

(C) DIRK OвBINK, 2016 | DOI: 10.1163/9789004314832_011

This is an open access chapter distributed under the terms of the Creative Commons Attribution- 
Wright (2015), who finds sexual imagery in the first two lines of the poem. Rather than referring to 'a commercially successful venture', he argues that the first lines may indicate 'something more than simply a good business trip'. Wright notes that whenever Charaxos comes up in our sources, his relationship with a prostitute is inevitably mentioned ('this account seems to be fused to his identity'), and, in what he dubs an example of 'Iambic Sappho' (although the poem is in Sapphics), ${ }^{2}$ he calls attention to nautical imagery used as a metaphor for sexual activity in Greek and Latin literature, including talking triremes in Knights who use aggressive sexual imagery, and ships being likened to women (Eq. 1300-1315). An ancient commentator claims that Alcaeus in a poem compares an aging hetaira to an old ship (Alcaeus fr. 306). Wright further reminds us that the 'language of filling' has been catalogued by Jeffrey Henderson as 'metaphorically sexual'. ${ }^{3}$ Read in this way, we can thus 'perceive a possible allusion to the sexual misadventures of Charaxos' and, according to Wright, such an allusion would fit in with other 'sexually charged language' in Sappho.

Problems arise, however, in trying to integrate this into the rest of the poem. Wright is unable to work out a good answer to that, as this does not seem to be a theme that is followed up in the poem as it develops to its conclusion. It also seems unlikely that something this indirect would justify Alexandrian scholars labelling Sappho a writer of iambics.

However, one might add to Wright's analysis the point that the reference to a male's possessing or displaying 'full load' as a metaphor for sexual prowess, need, or arousal is a motif that is almost too common to need exemplification. ${ }^{4}$ As a double entendre (pace Wright), this would not preclude the allusion from conveying economic considerations in addition, since structures of power are often written into the economic sphere as well as into the sexual. One parallel line of inquiry seems at least initially attractive. It seems obvious to all, for example, that 'Charaxos' coming' ( $\mathrm{E} \lambda \theta \eta \nu$ ) with his ship has something to do with Herodotus' story, which, after all, is one in a long series in the Histories of stories that are principally about women's bodies. Could the 'full ship' of the Brothers

2 Wright (2015) specifically indicates that he does not think that this is the 'aggressive poem'

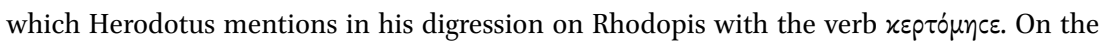
possible "iambic" stance of Sappho in the Brothers Song, see Martin, this volume.

3 Henderson (1975) 141, 161.49, 170.

4 See, however, Henderson (1975) 161-166 nos. 258-278 'Sexual Congress: Nautical Terminology'. This seems slightly more plausible than the scenario envisaged by Wright (2015), namely with the ship as the hetaira, "filled" by Charaxos, i.e. fucked by him. 
Song be an allusion to the promise (or perhaps threat) of Charaxos' returning with his ship laden with his prize 'cargo', namely the woman, however notorious, he was going to marry? ${ }^{5}$ It seems to have escaped the notice of everyone so far that Sappho, in a striking instance of what can only be called intertextual reference or self-citation (vis-à-vis the Brothers Song, line 5 , where she cites it as being frequently said by someone), prominently uses elsewhere the same verb,

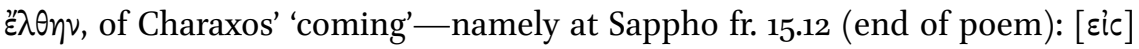
हैpov $\hat{\eta} \lambda \theta \varepsilon$ (Hunt), 'come for (i.e. because of) desire' (i.e. for someone). ${ }^{6}$ Here, as in the Brothers Song, Charaxos is probably the subject. ${ }^{7}$ In fact, in all four of the occasions that Sappho sings about Charaxos, he is always said to 'come' or 'may

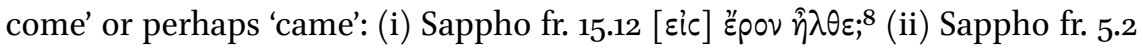

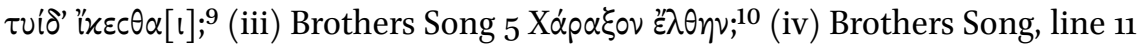

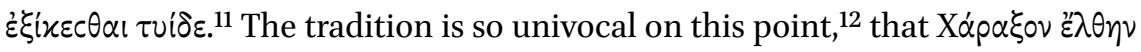
must have been something like a folk-tale (or song) motif, and we might even speak about a 'Charaxos-song', subject to a number of variations in meaning and story. Apart from the literal understanding of these verbs in their associated stories, Voigt in her apparatus on Sappho fr. 15, following Diehl, cites a

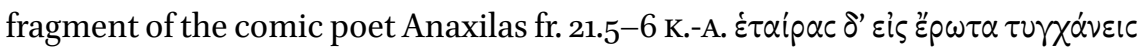
$\dot{\varepsilon} \lambda \eta \lambda \nu \theta \dot{\omega} c,{ }^{13}$ as a parallel for [ $[\dot{i c}]$ हैpov (+ genitive) in what is clearly an example

A weaker form of this thesis would be that such a correspondence might have been posited by Herodotus and ancient readers of the Brothers Song, which was then picked up by the ancient biographical tradition as a fact of history.

$6 \quad \operatorname{Or}[\ddot{\alpha} \psi] \varepsilon \rho \circ \nu \hat{\eta} \lambda \theta \varepsilon$ ('come again'), restored by Diehl (1936) ad loc.

7 See Lardinois, this volume, on the (less likely) possibility that Doricha is the subject.

8 Subject uncertain, but likely Charaxos (see above); location uncertain, but presumably wherever Charaxos and Doricha could be together; time: (negative) wish for the future.

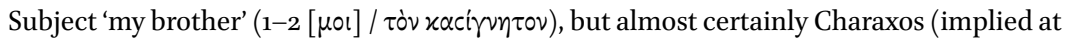
line $2 \chi \alpha \dot{\alpha} \alpha \nu \gamma \varepsilon \dot{v} \varepsilon c \theta \alpha$ l, the figura etymologica echoed by Posidippus Epigr. 17.3 Gow and Page

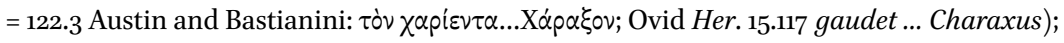
location: $\tau v^{i} \delta(\varepsilon)$, presumably Lesbos; time: wish for the future.

10 Subject: Charaxos; location unspecified; time: past or wish for future.

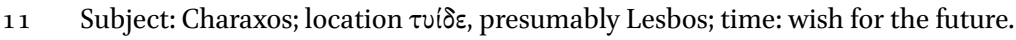

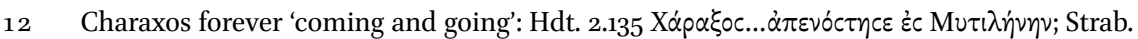

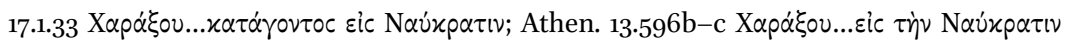

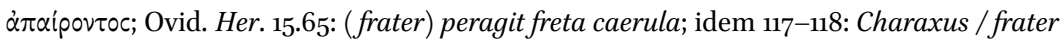
... itque reditque.

13 Not in Henderson (1975), but roughly equivalent, and related in meaning to (also not in

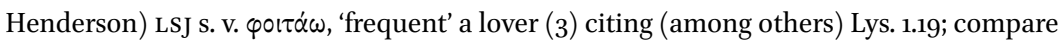

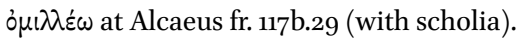


of talk referring to 'going to' or 'visiting' ( haps mean Charaxos was going to 'visit' her at Naucratis, ${ }^{15}$ as her client, or that he would 'come home' with her as his expensive bride? This might even lead to entertaining the first lines as being addressed to such a person, e.g. DorichaRhodopis, or generically to any such suitably alluring hetaira (named or not in the preceding lines) who might potentially attract Charaxos to a foreign port for a sexual liaison (or come home with him afterwards): 'You are always going on about his coming to (or 'with') you'.16

An additional consideration, set out below, will argue, however, against the presence of erotics per se in the Brothers Song, but without precluding a connection with the symposium which, it will be seen, has a oblique but significant side in Sappho's poetry, ${ }^{17}$ thereby revealing one motivation for some of the unusual language of the poem, while affording a link with Herodotus' biographical account as well.

\section{Sailing to Naucratis}

The new fragments show conclusively the alternation in book 1 of poems about family and cult, on the one hand, and personal concerns about love on the other. This is due to their chronological arrangement of age-grouped poems within each alphabetically arranged series of poem beginnings. ${ }^{18} \mathrm{~A}$ cycle of poems concerning sea-faring is revealed, centering on the drama of a mercantile family of wine-traders on 7 th century Lesbos. The presence of Dionysus in the trinity of gods in the Pan-Lesbian sanctuary at Messon on the island is explained, ${ }^{19}$ and the whole complex of ill-advised love, sea-faring, wine, and trade falls neatly into the context of Herodotus' story (2.135) of how

14 For $\hat{\eta} \lambda \theta \varepsilon$ in a sexual sense (= 'to visit a lover'), see explicitly LSJ s. v. B.7, citing Hdt. 2.115, 6.68, Xen. Oec. 7.5; Henderson (1975) 155 no. 229.

15 Posidippus Epigr. 17 (Gow and Page = 122 Austin and Bastianini) may be taken to describe the all-night symposium celebrating the 'arrival' of Charaxos at Naucratis in Egypt with Doricha (the epitaph supposedly on her tomb, the third and smallest pyramid at Giza according to some at Herodotus 2.134), while the final line hints at Charaxos' return (हैc $\tau^{\prime}$

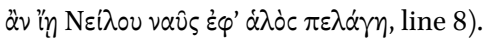

16 See Bowie, this volume, for the proposal that Doricha is the addressee.

17 On Sappho and the symposium, see further Bowie and Schlesier in this volume.

18 See Obbink, ch. 2, this volume.

19 For the cult of Hera, Zeus, and Dionysus at Messon, see the contributions of Boedeker, Caciagli, and Nagy in this volume. For the location of Messon, see Fig. 8.1, p. 199. 


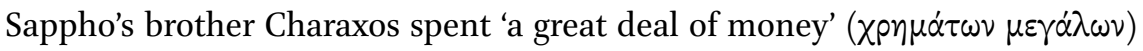
to free his lover, the courtesan Rhodopis (also known as Doricha), then a slave, at Naucratis in Egypt - for which Herodotus claims a pedigree in a poem of Sappho's. In Sappho frs. 15 and 5 and now the Brothers Song we can see the existence of a song type, a prayer for the safe return of the merchant-gone-tosea (or going). The prayer may rehearse an occasion leading to the performance of a song (as in the Brothers Song), or its actual performance in the past or present (as in Sappho fr. 5). It suggests a ritual occasion, not as regular as the blessing of the fleet, but required on multiple occasions, each needing a new song for performance. A merchant would put the family capital at risk more than once, until he became really rich, or, as the 'plausible' stories of Menelaus and Odysseus suggest, these were multi-year voyages. The prayer for safe return, introduced as a matter of concern, then expands to envisage what such a return would mean for the family - wealth, and an enhanced social position in the community. The emphasis shifts almost imperceptibly from the envisaged distress that sparks the prayer to the envisaged happiness that comes with the prayer's fulfilment, as happens in the erotic sphere in Sappho fr. 1, except that here the desired good becomes more specific or personal in the end, and may in each of the cases include or imply marriage. In Sappho fr. 5 at any rate, a connection with the poems involving Aphrodite is suggested, since she is also typically invoked in seaside cult as a protector of sailors (as we can see at the end of fragment 5 , perhaps associated with prostitutes and hetairae frequented by Charaxos).

But a separate sequence of poems from each group according to letter-incipit deals with love per se: Sappho fr. 16 on Anactoria who is longed-for by the speaker; Sappho fr. 16a on those who treat her badly, despite how well she treats them. So too the Kypris Song, addressed to Aphrodite, echoes Sappho fr. 1 , insofar as it delineates a chain of experiences of love. Homeric themes are touched on in both age-groups: in the love poems, we get Homeric language of battle in Sappho fr. 1; Helen leaving Menelaus in Sappho fr. 16. But also the kings leaving Ilium and coming to Lesbos in Sappho fr. 17, which is associated with nostos, perhaps that of the brother. ${ }^{20}$ Charaxos in the Brothers Song might be seen as an Odysseus figure (with Larichos as Telemachus) in a family drama with epic overtones. ${ }^{21}$

20 For this reading, see Neri (2014) and Caciagli, this volume.

21 Sappho $=$ Penelope, Doricha-Rhodopis $=$ Calypso or Circe. The correspondences are suggestive, but hardly exact. 
An aspect of this would mean becoming head of a household: an $\alpha$ unp or husband, and in Sappho the word may well carry that connotation. The point is not that Larichos should survive and grow up: he should become an $\alpha^{\prime} v \eta p$ in all senses. Presumably this would include marriage and the production of legitimate offspring. The paradigmatic importance of this to the community

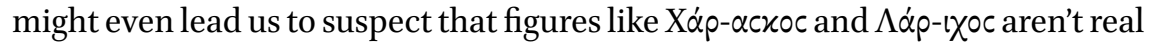
people in a historical or biographical sense, as it were, but rather perhaps cult figures in a wine merchants' ritual. They are also suitable names for a vinter's sons: $\lambda \dot{\alpha} p o c$ is used of wine (sense 'sweet'); $\chi \alpha \dot{\alpha} \alpha \alpha$ is the intoxicating joy and attractive grace that Dionysus brings. ${ }^{22}$ Furthermore, Brothers Song, lines 4-

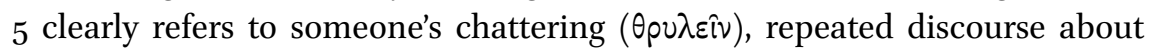
Charaxos' coming, as though a recognizable type or genre, and doing so in a particularly repetitive style. Sappho fr. 15 could well be the end of a 'Charaxos song'. Similarly Sappho sang a 'Phaon song', and one about a 'father' with the high-sounding Trojan-epic name Skamandronymos.

In the Brothers Song, Aphrodite doesn't appear. Instead we are told that Zeus, if he wills it, sends a special divinity as 'helper', ह̇ $\pi \dot{\alpha} \omega \omega \gamma o v$, to turn the distressed from their troubles. ${ }^{23}$ M.L. West proposed to emend the relatively

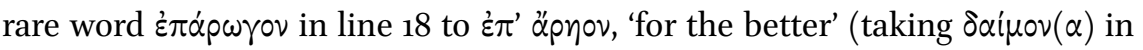
the sense of 'one's fortune'). ${ }^{24}$ Fortunately, we are now in a position to resolve this crux. Albert Henrichs has pointed out that $\beta \alpha c^{\prime} \lambda \varepsilon v c^{\prime} \mathrm{O} \lambda \dot{u} \mu \pi \omega$ in line 17 is in fact an extremely rare locution: a $\beta a c ı \lambda \varepsilon v$ c 'of Olympus' is mentioned nowhere earlier than Sappho in the present passage; and it occurs nowhere afterwards until Theocritus in his hymn (17) to Ptolemy II, in which in the closing climax, Zeus and Hera (in positive comparison with Ptolemy II and his wife Berenike) are styled as $\beta \alpha c \imath \lambda \hat{\eta} \alpha c^{\prime} O \lambda v^{\prime} \mu \pi 0 v .{ }^{25}$ In the same lines, Theocritus praises Ptolemy

22 For the brothers as stock figures in a ritual and/or traditional poetic entertainment, like Lycambes and the Lycambids in Archilochus, see Lidov, ch. 3, and Lardinois in this volume. For further etymologies of the names see Bierl, ch. 14, and Lidov, ch. 3, in this volume.

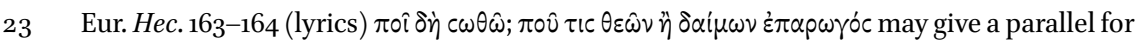
the variant $\dot{\varepsilon} \pi \dot{\alpha} \rho \omega \gamma o v$ recorded in the papyrus (Obbink [2014b] 44) and, if not actually an intertextual allusion to this verse of the Brothers Song, shows at least that the expression was a conceivable one in lyric poetry of the fifth century.

24 West (2014) 9: 'Those whose fortune the ruler of Olympus chooses to turn around from

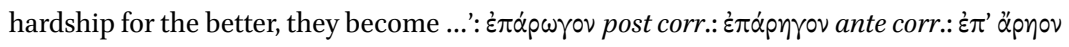

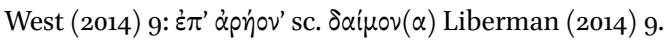

25 Henrichs (forthcoming). Theoc. Id. 17.132. Next at Verg. Aen. 5.533 where voluit rex magnus Olympi is a fair translation of $\beta \dot{o} \lambda \lambda \eta \tau \alpha \iota \beta \alpha c^{\prime} \lambda \varepsilon v c^{\prime} \mathrm{O} \lambda \nu^{\prime} \mu \pi \omega$ at Brothers Song, line 17 (see Aen.

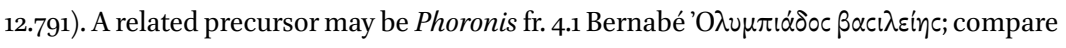

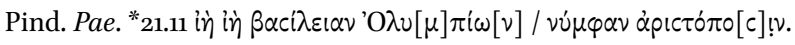


for having founded shrines (17.123 vaoúc) to his mother and father (Ptolemy

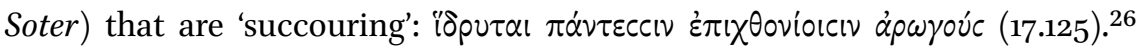
Given the rarity of the phrasing ( $\beta \alpha c^{\prime} \lambda \varepsilon v c^{\prime} O \lambda \nu \mu \pi \omega$ in line 17 at Brothers Song 17 and $\beta \alpha c i \lambda \hat{\eta} \alpha c^{\prime} O \lambda \dot{u} \mu \pi \circ v$ at Theoc. 17.132), and the linking of Zeus and Hera with the same title ( $\beta \alpha c i \lambda \hat{\eta} \alpha c)$ in both passages, Theocritus' allusion thus vindicates $\varepsilon \pi \dot{\alpha} \omega \omega \gamma o v$ as an attested reading in the Hellenistic text of the Brothers Song.

$\beta \alpha c i \lambda \varepsilon ı \alpha \nu$ "H $\mathrm{p} \alpha \nu$ at Brothers Song 10 is obviously connected with $17 \beta \alpha c i \lambda \varepsilon v e$ 'O $\mathrm{\lambda} \nu \mu \pi \omega$, especially given the attested connections of this epithet with Hera in the Lesbian sanctuary of the three gods at Messon, ${ }^{27}$ and the $\beta \alpha c^{i} \lambda \eta \varepsilon c$ at Sappho

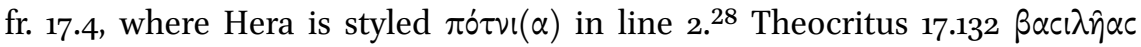

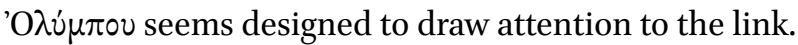

\section{A Role for Dionysus}

The linkage of Zeus and Hera, together with Charaxos' wine trading, raises the question of the absence in the Brothers Song of Dionysus, the third of the Lesbian trinity of deities in the Pan-Lesbian sanctuary at Messon. At the same time,

26 Pointed out to me by Renate Schlesier (private communication). This important intertextual reference cements the link between the two passages, showing (i) that Theocritus (like Horace after him) knew the Brothers Song, and (ii) that his text read ż $\alpha$ $\alpha \omega \gamma o v$ at Brothers Song 18 , not $\varepsilon \pi^{\prime}$ áp pov, as emended by West. Theocritus has slightly altered the epithet to $\dot{\alpha} \omega \omega \gamma$ oúc at 17.125, which is generally recognized (e.g. by Gow in his commentary

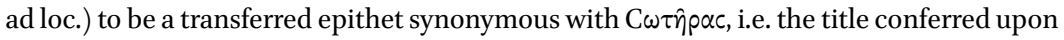
Ptolemy I already in his own lifetime, and which became part of the basis for his worship

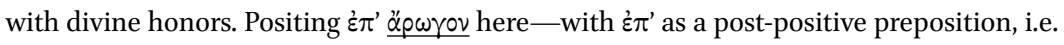

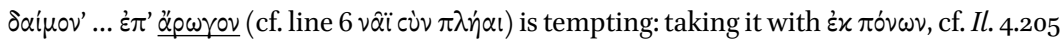

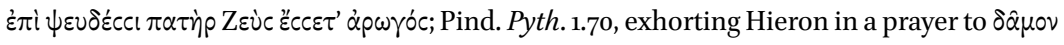

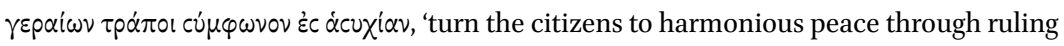
them' which offers a parallel with $\tau p \varepsilon \dot{\pi} \varepsilon i v$ and a prepositional phrase. But this would leave

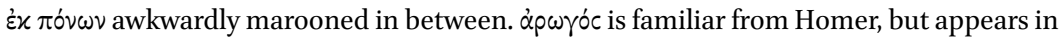

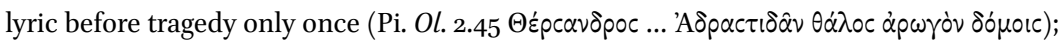
$\dot{\varepsilon} \pi \alpha \rho \omega \gamma o ́ c$ is not otherwise attested in early lyric or Pindar, and appears only once in Homer,

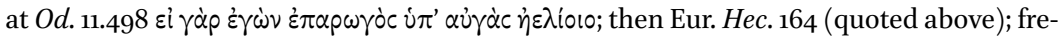
quently in Ap. Rhod. e.g. 4.196; Antipater, Ath. Pol. 6.219.21; Quint. Smyrn. 3.121.

As observed by Pirenne-Delforge and Pironti (2014) and Ferrari (2014) 3. They point to

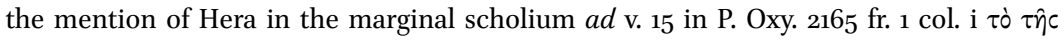

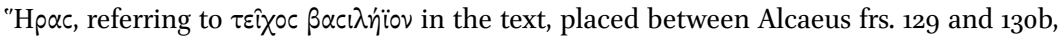
two poems set in the Pan-Lesbian sanctuary at Messon. 
Larichos' wine-pouring, Charaxos' wine-trading and, according to Posidippus, wine-drinking at the symposion all point in the direction of Dionysus. Perhaps he is in some vague way related to the unnamed protective daimon of line 18. It is Dionysus who releases the Zeus-chosen from their troubles and sins

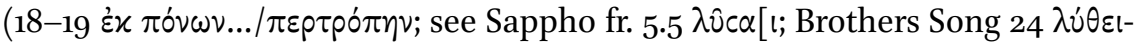
$\mu \varepsilon v)$ - presumably in blessed sympotic mysteries outside of which it would be sacrilege, or perhaps improper for a female poet, to name him. For this reason, perhaps, he is not mentioned by name here, either because of his worship in mysteries, not to be divulgated to the uninitiated, or because Dionysus (as the principal god of the male symposium) was outside a female poet's social world or age group; or perhaps he is simply unnamed as a kind of poetic riddle: Zeus is likewise obliquely styled here as 'King of Olympus' (without being named, unlike in line 6); and at Sappho fr. 17.10, Dionysus is obliquely called $\Theta v \omega$ vac i $\mu \varepsilon[\rho \operatorname{pov} \tau \alpha] \pi \alpha \hat{\delta} \delta \alpha$ without being mentioned explicitly by name (as Hera and Zeus are in that poem).

Alcaeus fr. 129.8-9 reveals his name in Lesbian form, but describes him

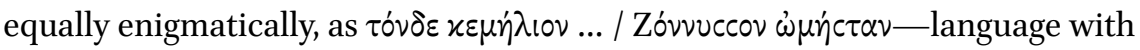
distinct connections to Orphic ritual and the Dionysiac mysteries. ${ }^{29}$ Dionysus is depicted elsewhere (e.g. in Hom. Hymn Dion. [7]) as the protector of sailors, and as such is sometimes connected with Nereids (see Sappho fr. 5.1). ${ }^{30}$ Similarly, Alcaeus fr. 34 is a prayer for helper-gods who save at sea; Sappho fr. 95 and Alcaeus 308, unless it narrated the same story as the Homeric Hymn to Hermes, contain prayers to Hermes, well-known as a helper god and escort. Through his protection, Dionysus confers the supreme status of the initiate: lines 19-

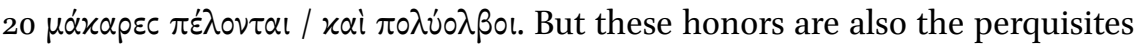
of the happy dead, ${ }^{31}$ so that, although the statement is framed in such a way as to apply to all humans, it is Charaxos who is offered this status as a recompense for death at sea - if the unnamed protecting deity-helper just happens to 'blow him a kiss' (Carson). Failure to name him makes fortune seem even more capricious - but also just as swiftly able to be turned to one's favor. Sappho's approach, instead, is a "sober" one, like wineless libations, offered to the protec-

29 Compare the Agathos Daimon, on whom see Burkert (1985) 180. He was worshipped in a heroic context in the cult of Dionysus. For Dionysus as $\delta \alpha i \mu \omega \nu$ see e.g. Eur. Bacch. 413:

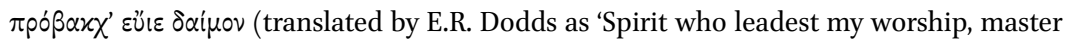

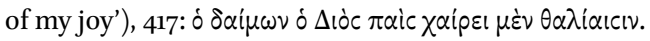

30 See Barringer (1995) 82, 149-151 who, quite apart from their mention in Sappho fr. 5, makes a case for the Nereids' connection elsewhere with Dionysus through their role in the ritual underworld eschatology of the Orphic Gold Leaves and the Dionysiac mysteries. 
tor guiding spirits of the netherworld, but without involvement in wine-making or drinking. Invoking Dionysus by name might be useful as a protector at sea, as he was by Alcaeus invoked as an avenger of Pittacus in the political sphere (and there is ample precedent for shipwreck as an emblem for political exile). But as a principal participant in adult male symposia, he may have been too far afield from the religious sphere of a young Sappho to warrant mention by name here.

In the coming of age of Lar-ichos in the final stanza (in addition to implications of class and marriage mentioned above), there may even be glimpsed a hope, expressed through a nautical allegory as in Alcaeus, for the success of the new crop and vintage and trading-voyage, and in the Char-axos story the passing away, through trade or sympotic consumption and enjoyment, of the old: a kind of Sapphic John Barleycorn, but with tokens of Dionysiac 'sacrifice' and reminiscent of the near contemporary 'Hymn to the Dyctaean Kouros' from Crete.

Apparently, the 'Charaxos song' can be sung either way, with the first line and a half of the Brothers Song perhaps spoken by someone else, addressed to Sappho, but partly quoting 'Sappho' (as Aphrodite does in Sappho fr. 1)-in

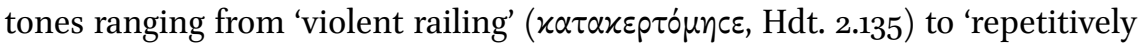
prattling' ( $\theta p u ́ \lambda \eta c \theta \alpha$, Brothers Song, line 5) - either about Charaxos' 'arriving (or not) with a full ship' and squandering the whole cargo on a whore in some port, and failing to come home with a ship full of spices and perfume-or, as a pious prayer for his safe and profitable return (as the Brothers Song continues, and in Sappho fr. 5). One version of the Charaxos song goes: 'Charaxos came (home once before), with a full ship', and another 'Charaxos came (to Naucratis) with a full ship (but didn't come home with one, or didn't come back)'; another

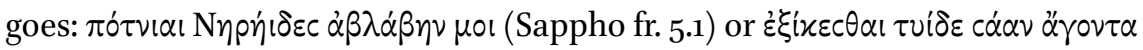

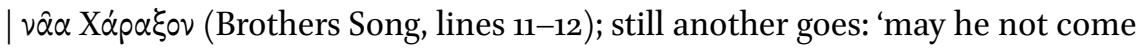
a second time for a longed-for desire' (Sappho fr. 15.11-12).

We might even see Charaxos and Larichos as helper-figures to sailors or a sea-going people, on the model of Castor and Pollux, as in Alcaeus fr. $34,{ }^{32}$ but attached to Dionysus (invoked obliquely in Brothers Song, line 18), who figure as characters in a drama centring on the trinity as gods of a mercantile city. For Sappho's audience, every "brother" at sea is a Charaxos, every youth at home is a wine-pouring Larichos, of ephebic status, on the verge of manhood (in the social sense; what for woman we now call a debutante). The notion of some element of social or ritual drama is an attractive one: every bride is a Helen—or: every maidens' chorus has a Helen (as Claude Calame has said) 
to compete in the 'beauty contest' in Lesbos which is also a re-enactment of an event narrated in the poetry of the Epic Cycle. Every girl has a father with a high-sounding Trojan war sounding name like Skamandronymos, a brother with an epic compound name like Erigyios, and a tragic lover with a name like Phaon. The poetry would then in general be scripts for such drama, but the preparation of the performers and the choosing of the participants would be part of it, too (see Sappho fr. 23), as they seem to be in Alcman.

Sappho thus concludes the Brothers Song by challenging her audience to remember that Charaxos' success and safety is in the hands of the gods and attainable (if at all) only through the correct form of prayer in song. Against this is held up universal knowledge of all the gods and the cosmos by the speaker (perhaps of wrongdoing, perhaps of Dionysiac salvation), and the power of hymnic song, framed in the poem, to help secure Charaxos' safety, as well as the safety and prosperity of the family or community. She looks forward to his thus returning to Lesbos, and imagines and advises how one would have to pray to the gods to secure this, and what he himself would need to wish for in order to secure safe passage, and so exonerate himself - and in the course of which she herself does so: i.e. performs this hymnic prayer - putatively in the future, just as in Sappho fr. 1 she reperforms one that she narrates in the past, thus bringing it into the immediacy of the present.

\section{How the Brothers Song Began}

The absence of a named Dionysus leads us back to the question of the addressee in line 5. To whom is the first complete line of the Brothers Song addressed, and how did the poem begin? I think there are only two possibilities: ${ }^{33}$ the first, considered at the beginning of this chapter, is an alluring, Siren-like hetaira: Rhodopis or Doricha, who might have led the sea-farer off-course or accompanied him home as prize 'cargo'. Who ever stood a greater chance to benefit from Charaxos' arriving 'with a full ship', than her? ${ }^{34}$ The second is Sappho's

33 Despite the odd switch to the third person that would be required later in the poem, Stehle, this volume, argues that the addressee is Larichos. Lidov, ch. 3 , this volume, considers the possibility of speaker change after the address in line 5 , so that the speaker of the first complete stanza is the one addressed as 'you' in the second.

34 See Bowie, this volume. This would raise questions about the location of the addressee at the time she is addressed in the poem. Could a speaker in Sappho address someone of legendary status like Rhodopis, or anyone as far afield as Egypt, or in an uncertain location? 
mother, ${ }^{35}$ since she would have had a natural inclination to be concerned about both her son and the family's fortunes. She also seems to be addressed elsewhere in Sappho's poetry.

On this basis of the preserved traces, West further plausibly conjectures that the final adonian of the first stanza (P. Oxy. 2289 fr. 5 line 2) ended with the words $c \varepsilon, \mu \hat{\varepsilon}\left[\tau \varepsilon \rho .^{36}\right.$ It may be suggested (purely exempli gratia, but not without some support—see below) that the first line of the stanza similarly contained the word $\pi \dot{\alpha} \tau \eta \rho$, as follows:

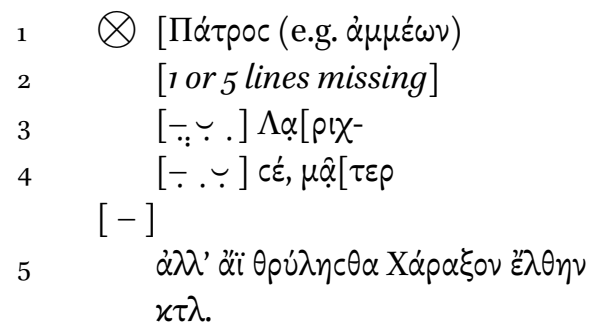

That Sappho mentioned her father (by name) in her poetry is known from references to him in Herodotus and ancient biographers. ${ }^{37}$ The specificity of

35 As argued in Obbink (2014b) 41.

36 West (2014) 14 The letter after $\mu$ is not certain (the lower-most part of a diagonal rising from the line of writing in the lower left quadrant, as of $\alpha \delta \lambda \mu$ ), but as West writes: 'The trace after $\mu$ can only be $\alpha$, since a vowel is required by the metre'. The pronoun cर́ is encouraged (if not guaranteed) by the presence of the accent in the papyrus, as it is at Sappho fr. 17.10 and Kypris Song = Sappho fr. 26.9. West notes that the space before ć 'seems impossibly narrow to accommodate two syllables, and if there was only one the alpha has to be short'. Although the possibilities for the latter are thereby delimited, there are line beginnings with two syllables in three letters in Sappho book 1 (fr. 16.19, fr. 35), and there also may have been run-over from Brothers Song, line 3 (see below). A narrow word like î $\alpha$ at the beginning of the adonian (originally restored by West, Maia 22 [1970] $327=$ Hellenica II 49 in the same position in Sappho fr. 17.20, see West [2014] 5) e.g. 3-4 [ Eic| i p $\alpha$ ]

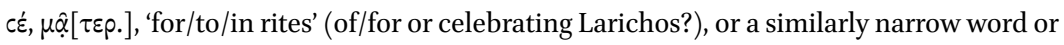
words consisting of a long followed by a short syllable, including the possible run-over of a word beginning in verse 3 (frequent in the adonian: Sappho fr. 1.12, 2.4, 5.16 and probably 20, 16.4 and 16, 16a.32, 30.5, 31.4, 8 and 12) and divided disyllabically as at 39.2-3 $\Lambda$ vi $10 v-$ would suit to fill the space of two (or at most three narrow) letters allowed. This, of course, does not prove that $\mu \hat{\alpha}[\tau \varepsilon \rho]$ is the correct restoration, only that it is a possible one.

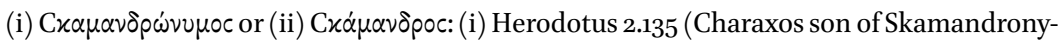
mos); Suda $\sigma 107$ (iv 322 f. Adler) (cf. $\Sigma$ Plat. Phdr. 235c; Tzetz. Proll. Com. 2.8); Ael. VH 12.19 (p. 135 Dilts); (i) or (ii): P. Oxy. 1800 fr. 1.1-35 = Sappho test. $25^{2}=$ Chamaeleon 29 3Т $C P F$ 
one distich in Ovid's Heroides (15.61-62) has led editors to infer an origin in her own poetry: ${ }^{38}$

\section{sex mihi natales ierant, cum lecta parentis}

ante diem lacrimas ossa bibere meas.

This distich introduces the section on Sappho's family and especially Charaxos that runs from lines 61-70, after which she returns to Phaon at line 71 and Charaxos is only vaguely alluded to (though named at lines 117-118). I suggest that the Brothers Song might have begun with a recollection of this sort. Such a chronology could account for how Sappho could have been young enough to have addressed her mother about her brothers, at a time when her younger brother was still young enough for his fortunes to be entirely uncertain. The sense will have been not 'Father is gone forever; move on!, but 'We've plenty to feel bad about; look on the bright side: do something pro-active!.

Also missing from the opening, I think, must be something about Larichos (the name restorable in line 3). Otherwise, he comes out of the blue at the end of the poem. ${ }^{39}$ Mention of him early in the poem, as a matter of concern or honor, will have formed a thematic frame with the end. We do not know what she said about him. But we are not without a clue. Horace alludes to Lar-i-chos in the

(vol. I 1* pp. 406-409); Jacobson (1974) 279-280. Ká $\mu \omega \nu$ (one of the variants on the name of Sappho's father at Suda $\sigma 107=\mathrm{iv} 322 \mathrm{f}$. Adler) is a hypochoristic form of the name. Connections of the name to the geography of the Troad and poetry about the Trojan war, and/or to Lesbian engagement in the Battle of Sigeum (cf. Alcaeus fr. 401b), may be relevant to Sappho frs. 16, 17 and 44 (among others).

38 'The information is so specific that it probably derives from some statement in her poetry': Knox (1995) 291 on Her. 15.61 sex mihi natales ierant, noting that the expression is unusual for 'my sixth birthday had passed', and that Ovid normally forms it with ago or adesse (Met. 2.497 natalibus actis, 13.753 and Met. 9.285 cum iam natalis adesset, Tr. 3.13.2). The latter consideration may be as relevant for inferring an earlier intertext as for establishing the authorship of Her. 15 .

At Brothers Song, line 22. Professor Lidov compares Horace's Ode 1.4: Solvitur acris hiems, in which Lycidas suddenly appears at the end: 'These twists which cast the whole preceding poem in a new light seem very Horatian, but he may well have modelled it on a type he found' (private communication). But the ambiguity encountered in the expression $\chi \varepsilon \varphi \dot{\alpha}-$ $\lambda \eta \nu \alpha$ ápp $\eta$ (as shown by modern commentators' and translators' uncertainty over it - the only expression in the poem rendered purely literally by Carson [2014], for example)-, shows that the later mention of Larichos at line 21 cries out for contextualization; and the fact that Horace makes Thaliarchos the addressee of his adaptation suggests a more prominent role for Larichos in Sappho's poem. 
person of (Tha)l-i-archos, the addressee of Odes 1.9, as Gregory Hutchinson has shown, ${ }^{40}$ as a puer who is also present at a symposium and exhorted to drink and not neglect love. Sappho will not have included the exhortation to drink, but the context of Alcaeus fr. 338 might well have been suggested to Horace (who had Sappho's poem in front of him) by Sappho's praise for Larichos as serving the city's elite as oivoxo $\omega \nu$ in the prytaneion of Mytilene: $C \alpha \pi \varphi \omega^{\prime} \tau \varepsilon \dot{\eta}$

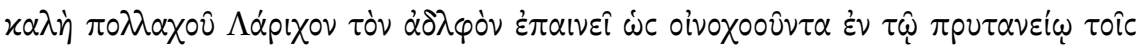

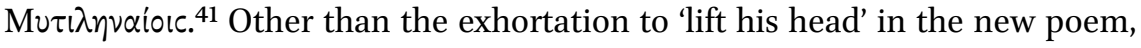
this is the only thing we know that Sappho said in her poetry about her younger brother. ${ }^{42}$

It might be objected that there is little space at the beginning of line 3 before $\Lambda \alpha[\rho / \chi$ - Although the line would start slightly to the right of the lines under it, the difference would not have been appreciable from one line to the next; and it must also be taken into account that Brothers Song, lines 34 'appear to be written smaller than the others' (Lobel [1951] 5), and so will have had slightly more letters than the same fragment has for Brothers Song, lines $5^{-8}$. So there is no problem with four letters at the opening of Brothers Song, line 3: line beginnings with two syllables in four letters (and word-break after the second syllable) are extremely common in Sappho Book 1, and thus nothing prevents restoring $\Lambda \alpha[p(\chi-$ in Brothers Song, line 3. Of course, it could have had only three, with one or two wide letters. So it would be possible to restore instead Athenaeus' $\pi \circ \lambda] \lambda \alpha[\chi \circ \hat{v}$ here (with Lidov, ch. 3, this volume), especially if Athenaeus's source is a paraphrase or inference from an actual statement. However, it is hard to see how Sappho herself could have used the word as Athenaeus' speaker does (she is unlikely to have credited herself with praising Larichos 'often'). And had she praised Larichos here for 'often pouring the wine', Athenaeus' speaker might have been expected to have just said so

40 Hutchinson (2014) 288-289, noting inter alia that in Horace $\theta \alpha \lambda$ i $\alpha$ has been imported from pre-58 Cologne, lines 6-7, and that Horace, Carm. 1.9.9-12 covers Brothers Song, lines 13$16\left(\tau \dot{\alpha} \delta^{\prime} \alpha^{\prime} \lambda \lambda \alpha, 13=\right.$ cetera, Carm. 1.9.9; Nisbet and Hubbard (1970) ad loc.: 'everything outside the symposium') + Alcaeus fr. 338.2-7; see Hutchinson in Obbink (2014b) 43, Phillips (2014), Morgan (2014) and in this volume.

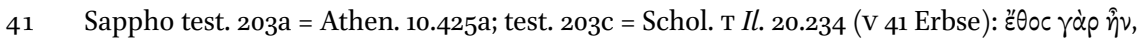

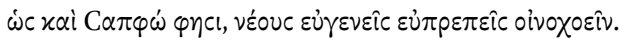

42 According to P. Oxy. 1800 fr. 1.1-35 = Sappho test. $25^{2}=$ Chamaeleon 29 3T CPF (vol. I 1*

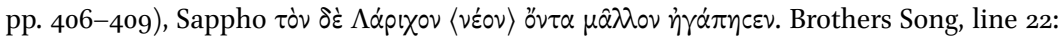

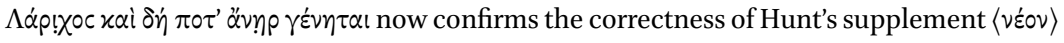
in Grenfell and Hunt (1914) as the missing adjective before ő $v \tau \alpha$, as noted by Liberman (2014) 3. The poem may have been the source of these testimonia. 
instead of turning this into her 'often praising him' for doing so. If Sappho indeed, as Athenaeus says, 'often' praised him for pouring the wine, it increases the chances that she did so in this poem in which we, after all, now know that Larichos was mentioned.

References to wine per se are lacking in Sappho, unlike in Alcaeus, and references to wine-pouring are rare, but not entirely absent: in Sappho fr. 141,

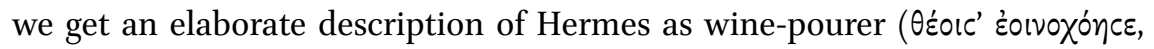
line 3) at a divine wedding quoted by Athenaeus at $10.425 \mathrm{~d}$, not long after the mention of Sappho's praise for Larichos. ${ }^{43}$ Sappho fr. 2.16 oivoxóalcov compares wine-pouring to 'nectar-pouring. ${ }^{44}$ Athenaeus 11.487a quotes Diphilus' Sappho (Sappho test. 26 Campbell) for a comico-symposiastic wine-pouring scene involving the poetess (doubtless reflecting how commonly her poetry was later performed at Athenian parties). Posidippus, on the other hand, specifically says of Doricha, carousing into the wee hours with Charaxos, that she 'grasped

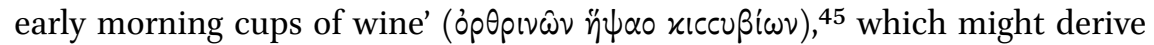
from a reference in a lost poem Sappho's. Presumably Sappho said of Larichos that (something after the example of Ganymede) it was an honor to have been chosen as a wine-pourer, from which the family, perhaps under unusually trying circumstances, might benefit. ${ }^{46}$ It would have been cause for celebrating, as the conclusion of the Brothers Song underscores.

A reference to the gaity and levity of the celebration, and of the banquets in the prytaneion at Mytilene, would not have been out of place. The events at which Larichos is envisaged as present would have been graced with the presence of attractive young boys for the enjoyment of the male elite. It would not be entirely out of place for Sappho to have said: 'Now Larichos will (have to) box with Eros', or 'Now they (sc. adult males) will find Eros a tough opponent'a topos familiar from Anacreon. ${ }^{47} \mathrm{~A}$ gentle tease of this sort would explain the

43 Suggested by Lidov (2002) 220 n. 39 as a possible place for Sappho's mention of Larichos' role as wine-pourer; see Sappho test. 203b = Eust. Il. 1205.17ff.: C $\alpha \pi \varphi \dot{\omega} \delta \dot{\varepsilon} \dot{\eta} x \alpha \lambda \dot{\eta} \tau \dot{\partial} v{ }^{~ E} \mathrm{E} \mu \mu \hat{\eta} \nu$

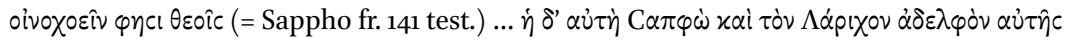

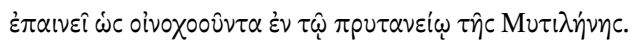

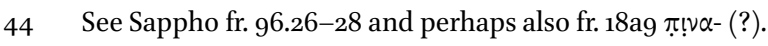

45 Epigr. 17.4 Gow and Page $=122.4$ Austin and Bastianini.

46 See Lardinois in this volume.

47 'The proposal to fight heightens the tension of eros' (P.J. Parsons, private communication). It feigns resistance, as it acknowledges risk: Larichos could get hurt, or may have already been hurt (or abused) by someone. See further MacLachlan (2001). For the image, Anacreon fr. 396: 'Bring water, boy, bring wine, bring me garlands of flowers: fetch them,

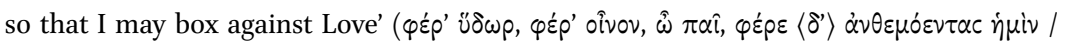




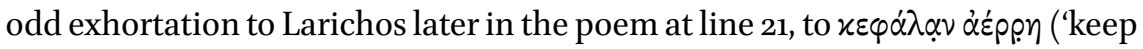
his head up in the fray'). In fr. 346 Anacreon speaks of looking up and holding up his head after boxing with a difficult partner, Eros: ${ }^{48}$

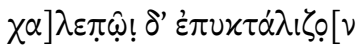

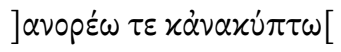

] . $\omega \iota \pi \circ \lambda \lambda \dot{\eta} \nu \dot{\partial} \varphi \varepsilon i \lambda \omega$

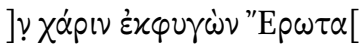

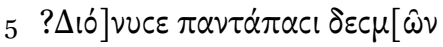

]. $\chi \alpha \lambda \varepsilon \pi \omega \hat{\omega} \nu \delta \iota^{\prime}$ 'A $\varphi \rho \circ \delta i \tau \eta[v$.

]

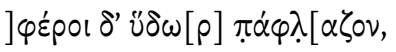

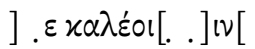

10

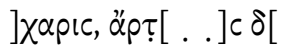

It is significant that whereas in Anacreon fr. 357 Eros and Aphrodite are named as playmates of Dionysus, fr. 346 may serve to pit Dionysus against the two erotic deities (reading an address $\Delta$ ió]vvce at the start of line 5 in fr. 346). It thus contains a conscious shift away from the inner, erotic struggles of the narrator and into the curative merrymaking of the celebration. For Larichos in the Brothers Song, it may be that Dionysus (in the guise of the unnamed daimon) interrupts the combative atmosphere of the brother's fight with Eros, and aids our transition into the convivial context. At the same time the image would provide a plausible precedent for Horace's advice to his addressee, Thaliarchos. The sequence of thought, then, as suggested above, would be as follows:

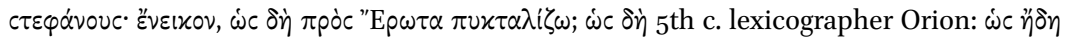
Et. Gen.: $\dot{\omega} c \mu \eta \dot{\eta}$ Athenaeus, Eustathius, and the 2nd century Anacreon portrait mosaic from Autun [see Blanchard (1975)]: ‘́c $\alpha \nu$ Dobree). Campbell (1967) 326 compares Soph. Trach.

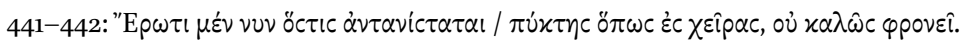

48 Anacreon fr. 346 (2) fr. 4 (P. Oxy. 2321 fr. 4), a hymn to Dionysus (?): '... and I was boxing with a tough opponent, (but now) I look up and raise my head again ... I owe many thanks, (Dionysus?), for having escaped Love's bonds completely, bonds made harsh by Aphrodite. Let wine be brought in a jar, let bubbling water be brought, let ... be summoned ... grace, (perfect?) ...' (tr. Campbell). See Anacreon fr. 396.2"E $\rho \omega \tau \alpha \pi \nu x \tau \alpha \lambda i \zeta \omega$. I owe this suggestion to Renate Schlesier, who will develop it elsewhere. See also Lidov, ch. 3, and Bierl, ch. 14, in this volume. 


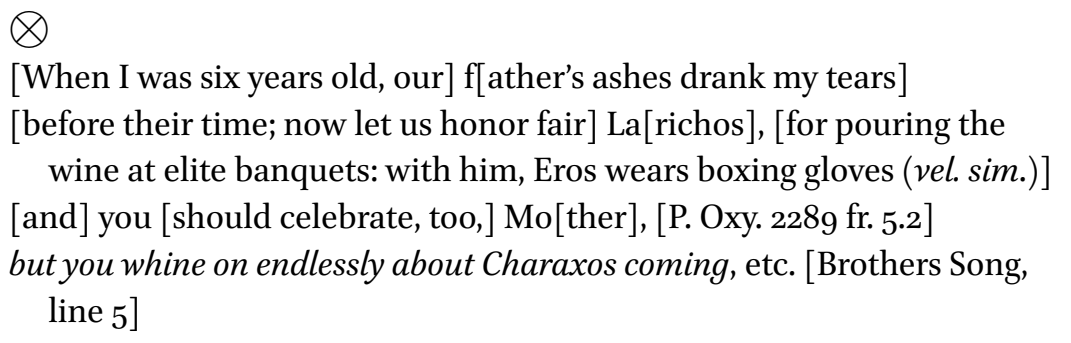

The boat and weather imagery that follow in the Brothers Song could have easily been understood by Horace and his Roman readers as part of a repertoire for thinking about the symposium. Horace's 'Soracte ode' (Carm. 1.9) will have been a creative rethinking of the Brothers Song, answering a Sapphic intertext with one from Alcaeus (fr. 338), and envisaging what he (or a symposiast) might have spoken to the young "Larichos" from Sappho's poem at the prospective banquet. Wine = Dionysus (the 'helping daimon') may also be hinted at in the poem as the antidote for Charaxos' love-troubles-or so Horace might have read Sappho's poem allegorically.

But how to integrate this into the rest of the poem? On the one hand, it makes these lines not sympotic (for Sappho will not have mentioned the symposium), but only convivial. The boxing lover is embroiled with (not frugally avoiding) boys or courtesans, and he is not a potential spouse for the daughters of the male aristocrats. One would have to infer from this image of the convivial life the social standing that would 'free us from sorrows' required for the last two lines despite the complete change of tone and substance.

But this is in fact what the Brothers Song goes on to do: the speaker contrasts the addressee's doldrums over the errant brother, with a correlative response: while young Larichos is teased about having it off with the aristocrats (into whose families he might marry, or from whom he could expect an introduction into elite society), Sappho bids her addressee engagement in a parallel celebration at a festival, including the performance of a prayer or hymn and the enactment of a rite. The uncertainty of events is balanced off against trusting in the gods' fore-knowledge of events, leading (Zeus willing) to blessed pros-

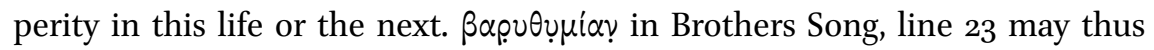
have an ironic or mocking tone, comparable to the reference to her $\beta \alpha \dot{\alpha} \nu v c \delta \dot{\varepsilon}$ $\mu^{\prime} \partial[\theta] \hat{\nu} \mu \circ c$ in the 'Tithonos Song' (Cologne Sappho, line 5). In this way, the Brothers Song would have a subtle but justifiably jubilant up-turn at the conclusion, after coping with dire circumstances, paralleled in a number of her other poems' endings.

But it would not be an erotic poem, any more so than Horace's 'Soracte ode' is an overt invitation to eroticism, and as such coheres with expectations for this 
series of poems (Sappho frs. 17, 18, 18a, 5 , and 9-which together stood at the beginning of the group with incipits in $\Pi-$, and before the overtly erotic Kypris Poem). Its direction will have been for hopes for the family under uncertain circumstances, wishing into existence a better social, financial, and religious status, and the vanishing of family gloom, but parallelled by the manner in which Sappho's erotic poems frequently are couched as pleas for the relief of anxiety over love. ${ }^{49}$

49 Neri $(2015) 56$ n. 16 objects that this reconstruction of the opening strophe would be out of keeping with the anxious mood of the following verses $\left(5^{-6}\right)$, but those prattling concerns are those of the interlocutor, not of the speaker / Sappho, who counters them in an altogether different, more modulated tenor. 